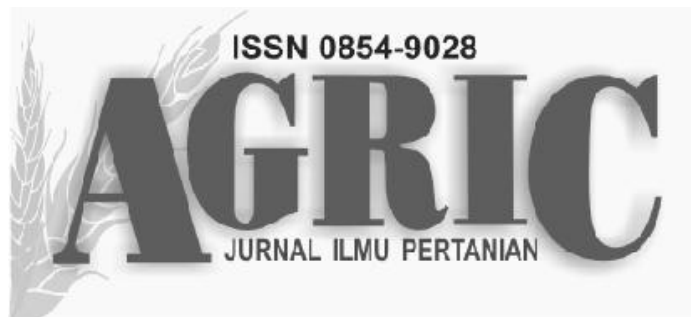

Fakultas Pertanian dan Bisnis Universitas Kristen Satya Wacana Jl. Diponegoro 52-60 SALATIGA 50711 - Telp. 0298-321212 ext 354 email: agric_fpb@yahoo.co.id, website: ejournal.uksw.edu/agric

\title{
SKRINING FITOKIMIA DAN AKTIVITAS ANTIBAKTERI in vitro EKSTRAK HEKSANA-PETROLEUM ETER Artemisia cina Berg. ex Poljakov
}

\section{THE PHYTOCHEMICAL SCREENING AND in vitro Antibacterial ACTIVITY OF HEXANE-PETROLEUM ETHER EXTRACT OF Artemisia cina Berg. ex Poljakov}

\author{
Elizabeth B.E. Kristiani \\ Fakultas Biologi Universitas Kristen Satya Wacana \\ J1. Diponegoro 52-60 Salatiga \\ betty@staff.uksw.edu \\ Sri Kasmiyati \\ Fakultas Biologi Universitas Kristen Satya Wacana \\ J1. Diponegoro 52-60 Salatiga \\ kas@staff.uksw.edu \\ Maria M. Herawati \\ J1. Diponegoro 52-60 Salatiga \\ maria@staff.uksw.edu
}

Program Studi Agroekoteknologi Fakultas Pertanian dan Bisnis Universitas Kristen Satya Wacana

Diterima 2 Februari 2015, disetujui 1 Juni 2015

\begin{abstract}
The objectives of this reserch were to determine the antibacterial activity of hexane-petroleum ether $(1: 1 \mathrm{v} / \mathrm{v})$ extract of Artemisia cina Berg. ex Poljakov on Escherichia coli and Staphylococcus aureus and its compounds. The design of the research was using completely Randomized Design in five concentration of extract that were 0, 50, 75, 100, 150, dan $200 \mathrm{mg} / \mathrm{ml}$ with four repliceted. Ethanol $60 \%$ was used as negative control and tetracycline as positive control. There were three steps of research. First step was extracted the plant using soxhlet method with hexane-petroleum ether $(1: 1 \mathrm{v} / \mathrm{v})$. Second step was determined the antibacterial activity of hexane-petroleum ether $(1: 1 \mathrm{v} / \mathrm{v})$ extract in various concentration of that extracts on E. Coli and $S$. aureus using agar diffusion method. Analysis of Variance (ANOVA) and was used to determined the significan different of diameter of inhibition between the treatments. Thirdsteps was phytochemical analysis of extract. The highest antibactrial activity on E. Coli was at $100 \mathrm{mg} / \mathrm{ml}$ whereas on S. Aureus at $150 \mathrm{mg} / \mathrm{ml}$. That extract was contained flavonoid, alkaloid, essential oils, saponin, sterol, tritepene, hydrolized tannin, and coumarin.
\end{abstract}

Keywords: Artemisia cina Berg ex Poljakov, Bacterial, Escheria coli, Staphylococcus aureus 


\section{PENDAHULUAN}

Antibiotik termasuk jenis obat yang cukup sering diresepkan dalam pengobatan modern. Antibiotik mampu menghambat pertumbuhan mikroorganisme lain atau bahkan membunuhnya. Setiap antibiotik beragam kefektifannya dalam melawan berbagai jenis bakteri. Ada antibiotik yang aktif terhadap bakteri gram positif, bakteri gram negatif, atau kedua-duanya. Akan tetapi, pemakaian antibiotika dalam jangka panjang dapat menyebabkan sifat resistensi dari mikroorganisme terhadap antibiotik yang digunakan (Dwiyanto 2001). Paradigma tersebut memunculkan langkah alternatif untuk menggali senyawa lain yang mempunyai aktivitas antibakteri. Masyarakat cenderung lebih memanfaatkan tumbuhan sebagai obat alternatif karena dianggap relatif lebih aman dan ramah lingkungan dibandingkan obat-obatan sintetis, dan dari segi biaya relatif lebih murah. Salah satu dari jenis tanaman berkhasiat tersebut adalah tanaman herba Artemisia.

Artemisia merupakan salah satu famili Asteraceae yang memiliki kemampuan pengobatan oleh kandungan minyak esensial dan metabolit sekunder (Ahameethunisa dan Hopper, 2010). Beberapa penelitian tentang aktivitas antibakteri dari ekstrak Artemisia juga telah dilakukan oleh beberapa peneliti. Secara global, Tan et al. (1998) menyebutkan beberapa senyawa kimia yang berperan sebagai antibakteri pada tanaman Artemisia, yaitu minyak asiri, monoterpenes, flavonoid, sesquiterpene lactone, $\alpha$-santonin dan asam artemisinin. Ekstrak heksana daun $A$. nilagirica menunjukkan aktivitas antibakteri terhadap berbagai bakteri gram positif dan gram negatif (Ahameethunisa dan Hopper, 2010). Fraksi air $A$. indica menunjukkan maksimum aktivitas terhadap B. subtilis ((Bibi et al., 2011). Ekstrak methanol dan etanol daun A. аппиа menunjukkan aktivitas antibakteri terhadap $S$. aureus PTCC 1431, Salmonella enterica PTCC 1231, Klebsiella pneumonia PTCC 1053, Shigella dysenteriae PTCC 1188 and E.coli PTCC 1399 menggunakan metode difusi agar (Tajehmiri et al., 2014). Hasil penelitian El-Sayed et al. (1988) dalam Tan et al. (1998) menunjukkan bahwa A. cina Berg. ex. Poljakov memiliki aktivitas antibakteri terhadap $B$. subtilis dan $B$. cereus dengan kandungan $\alpha$-santonin yang berperan sebagai senyawa antibakteri. Pengujian antibakteri oleh Stermitz et al. (2002) terhadap $S$. aureus dan $P$. falciparum memperlihatkan adanya aktivitas antibakteri dengan menggunakan tanaman A. cina. Kalemba et al. (2002) juga berhasil membuktikan bahwa $A$. asiatica Nakai memiliki aktivitas antibakteri terhadap B. subtilis, $S$. aureus, E. coli dan $P$. aeruginosa. Namun sejauh ini, belum dapat ditemukan pengujian antibakteri dari berbagai jenis Artemisia terhadap jenis bakteri Serratia sp. Daun A. vulgaris yang diekstrak menggunakan kloroform, petroleum eter, etil asetat, dan air menunjukkan aktivitas antimiroba secara nyata dibandingkan dengan antibiotika standar. Ahmadizadeh et al. (2014) juga melaporkan aktivitas antibakteri ekstrak methanol daun $A$. vulgaris terhadap $S$, aureus dan B. cereus.

Beberapa Artemisia telah diketahui memiliki potensi sebagai bahan antibakteri antara lain $A$. dracunculus L., A. absinthium, A. santonicum, dan A. spicigera (Kordali et al. 2005; Jazani et al. 2011; Raeisi et al. 2012; Habibipour \& Rajabi 2015 ), A. herba-alba asso (Imeluane et al. 2010; Zouari et al. 2010), A. absinthium (Moslemi et al. 2012), A. аппиа (Tajehmiri et al. 2014), A. afra Jacq. Ex Willd. (More et al. 2012); A. afra (Muleya et al. 2014), A. maritima (Sharma et al. 2014), A. anomala S. Moore (Guangrong et al. 2008), A. parviflora (Ahameethunisa dan Hopper, 2012), A. iwayomogi Kitamura (Cha 2007), A. capillaris Thunb (Kim et al. 2004; Joshi et al. 2013), A. lavandulaefolia DC (Zhang et al. 2012), A. douglasiana (Setzer et al. 2004), A. kermanensis Podl. (Kazemi et al. 2011), A. montana Pamp. (Kim et al. 2013). Sejauh ini belum dilaporkan potensi aktivitas khususnya Artemisia cina yang merupakan salah satu jenis Artemisia yang banyak tumbuh di Indonesia.

Penelitian ini bertujuan untuk mengetahui adanya aktivitas antibakteri dari Artemisia yang dapat tumbuh di Indonesia, yaitu khusus pada A. cina. Pengujian dilakukan dengan menggunakan ekstrak Artemisia cina Berg. ex Poljakov tersebut yang dilarutkan dalam campuran pelarut heksanapetroleum eter (1:1). Potensi aktivitas antibakteri akan diujikan pada dua jenis bakteri dalam 
golongan berbeda yaitu E. coli dalam kelompok bakteri gram negatif dan S. Aureus dari kelompok bakteri gram positif. Adanya aktivitas antibakteri ekstrak yang diperoleh ditentukan berdasarkan kemampuan ekstrak dalam menghambat pertumbuhan bakteri uji. Selain itu, pada penelitian ini juga dilakukan penapisan fitokimia untuk mengetahui secara kualitatif jenis-jenis senyawa yang mengkin berperan dalam aktivitas antibiotik. Hasil dari penelitian ini diharapkan dapat menambah informasi tentang tanaman yang berpotensi sebagai tanaman obat khususnya yang mempunyai kemampuan sebagai bahan antibiotika alami.

\section{BAHAN DAN METODE}

Preparasi materi tanaman. Tanaman segar diperoleh dari Balai Besar Penelitian Tanaman Obat dan Obat Tradisonal (B2PTO2T) Tawangmangu Jawa Tengah. Tanaman A. cina Berg. ex Poljakov dikeringanginkan tanpa paparan matahari langsung. Setelah kering, tanaman diblender sehingga menjadi serbuk.

Preparasi ekstrak. Serbuk tanaman diekastraksi secara maserasi menggunakan pelarut pelarut campuran pelarut heksana-petroleum eter (1:1). Ekstrak dipekatkan menggunakan rotary evaporator dengan pemansan 40R"C Sebelum digunakan, ekstrak pekat yang diperoleh disimpan pada suhu $4 R^{\prime \prime} C$. Pembuatan seri konsentrasi ekstrak menggunakan pelarut etanol dan akuabides dengan konsentrasi akhir etanol pada setiap perlakuan sebesar $60 \%$.

Uji Antibakteri. Uji ini menggunakan rancangan acak lengkap (RAL) dengan 5 tingkatan kadar ekstrak yaitu 0, 50, 75, 100, 150, dan $200 \mathrm{mg} / \mathrm{ml}$. Etanol 60\% digunakan sebagai kontrol negatif sedangkan antibiotik standart tetrasiklin $10 \mathrm{mg} /$ ml digunakan sebagai kontrol positif. Ulangan dilakukan sebanyak 4 kali. Medium pertumbuhan nutrien agar yang telah disterilkan disiapkan dalam cawan petri yang juga telah disterilkan. Setelah medium memadat, permukaan medium dispread dengan satu jenis bakteri uji. Sementara itu, kertas cakram ditetesi dengan $25 \mu \mathrm{L}$ larutan uji. Sumuran yang telah ditetesi dengan larutan uji diletakkan pada permukaan cawan petri yang telah dispread dengan bakteri. Cawan petri dibungkus dengan kertas dan diinkubasi di dalam inkubator pada suhu $37^{\circ} \mathrm{C}$ selama 2 x 24 jam. Setiap selang waktu 24 jam, dilakukan pengukuran zona terang yang terbentuk di sekeliling kertas cakram, yang disebut dengan Daerah Daya Hambat (DDH).

\section{Penapisan Fitokimia dengan Metode Ciulei (Budiyanto 2006).}

\section{Flavanoid}

Ekstrak diuapkan hingga kering, kemudian dilarutkan dalam 4-5 tetes $\mathrm{HCl}$ pekat. Munculnya Warna merah atau merah ungu menunjukkan adanya kandungan flavon, sedangkan warna oranye menunjukkan adanya kandungan flavonon

\section{Alkaloid}

Sebanyak 2 gram ekstrak dilembabkan dalam 3$5 \mathrm{ml} \mathrm{NH}$ pekat, lalu digerus menggunakan mortar. Selanjutnya ditambahkan $20 \mathrm{ml}$ kloroform dan digerus ulang sampai homogen, kemudian disaring. Filtrat yang diperoleh diteteskan pada kertas saring, kemudian ditetesi lagi dengan reagen Dragendorff sampai terbentuk warna jingga yang menunjukkan uji positif adanya alkaloid. Sisa filtrat diekstraksi dua kali menggunakan $\mathrm{HCl} 10 \%$. Ke dalam 2 buah tabung reaksi masing-masing dimasukkan $5 \mathrm{ml}$ filtrat hasil ekstraksi. Tabung reaksi I diberi 2-3 tetes reagen Meyer, sedangkan tabung II diisi 2-3 tetes reagen Dragendroff. Reaksi positif ditunjukkan dengan munculnya endapan kekuningan pada tabung I dan endapan oranye/jingga pada tabung II menunjukkan adanya alkaloid.

\section{Minyak asiri}

Ekstrak diuapkan hingga kering. Jika ada bau enak pada residu, dilanjutkan dengan penambahan beberapa tetes etanol, kemudian diuapkan kembali. Masih adanya bau enak hasil proses penguapan menunjukkan adanya minyka asiri dalam ekstrak.

\section{Saponin}

Sedikit ekstrak dimasukkan ke dalam tabung reaksi kemudian ditambah dengan akuades (ekstrak Artemisia : akuades =1:1) dan dikocok selama 5 menit. Gumpalan busa yang muncul 
dengan ketinggian minimal $1 \mathrm{~cm}$ dan bertahan selama \pm 15 menit mengindikasikan adanya saponin.

\section{Sterol dan Triterpena}

Ekstrak diuapkan hingga kering, kemudian residu dilarutkan ulang dalam tabung reaksi menggunakan $0,5 \mathrm{ml}$ asetat anhidrat dan $0,5 \mathrm{ml}$ kloroform. Campuran tersebut ditetesi dengan 1$2 \mathrm{ml} \mathrm{H}_{2} \mathrm{SO}_{4}$ pekat perlahan-lahan melewati dinding tabung reaksi. Terbentuknya cincin violet atau merah kecoklatan di sekitar dinding tabung reaksi menunjukkan uji positif adanya sterol dan triterpena.

\section{Tanin}

Ekstrak dilarutkan dalam $10 \mathrm{ml}$ air panas, ditambah dengan 5 tetes $\mathrm{NaOH} 10 \%$ kemudian disaring. Filtrat dibagi dalam 3 tabung reaksi (i) kontrol; (ii) ditambah 3 tetes larutan gelatin, Munculnya endapan di dasar tabung menunjukkan adanya tanin. Apabila endapan tidak ada berarti ekstrak mengandung polifenol; (iii) ditambah dengan 1-2 tetes larutan $\mathrm{FeCl}_{3}$. Adanya warna biru kehitaman menunjukkan kandungan hydrolisatetanin sedangkan hijau kecoklatan menunjukkan adanya katekol (tanin terkondensasi).

\section{Kumarin}

Ekstrak diuapkan hingga kering, dilarutkan dalam air panas kemudian didinginkan. Campuran dibagi ke dalam 2 tabung (i) kontrol; (ii) ditambah dengan $0,5 \mathrm{ml} \mathrm{NH}_{3} 10 \%$. Pijaran yang kuat di bawah sinar UV mengindikasikan adanya senyawa kumarin dan turunannya.

\section{ANALISIS DATA}

Data kuantitatif nilai DDH dianalisa secara statistik menggunakan analysis of Variance (ANOVA). Apabila terdapat perbedaan nyata perlakuan dengan kontrol, uji dilanjutkan dengan uji BNJ pada taraf uji 5\%.

\section{HASIL DAN PEMBAHASAN}

Preparasi ekstrak tanaman A. cina Berg. ex Poljako meliputi beberapa proses antara lain pengeringan tanaman, pembuatan serbuk tanaman, maserasi serbuk tanaman, dan pemekatan hasil maserasi sehingga diperoleh ekstrak untuk diuji aktivitas antibakteri dan analisis fitokimia (Gambar 1).

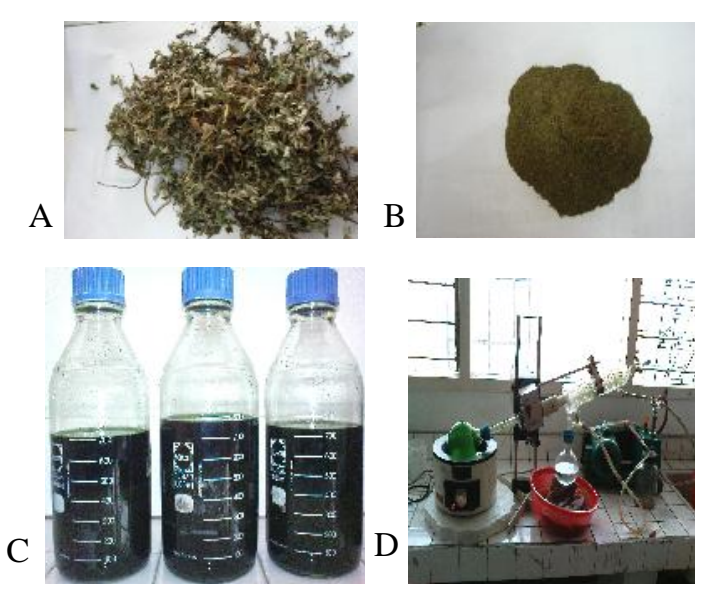

Gambar 1.Beberapa tahapan dalam preparasi ekstrak tanaman A. cina Berg. ex Poljakov (A) tanaman kering Tanaman A. cina Berg. ex Poljakov; (B) serbuk hasil dari proses blender tanaman A. cina Berg. ex Poljakov; (C) proses maserasi serbuk $A$. cina Berg. ex Poljakov menggunakan campuran pelarut heksana-petroleum eter (1:1); (D) penguapan pelarut menggunakan rotari evaporasi

Adanya kemampuan ekstrak dalam menghambat pertumbuhan bakteri ditunjukkan dengan munculnya zona terang disekitar sumuran. Munculnya luasan zona terang tersebut merupakan petunjuk adanya kepekaan bakteri uji terhadap bahan antibakteri yang digunakan. Respon penghambatan pertumbuhan bakteri terhadap pemberian ekstrak Artemisia cina Berg. ex Poljakov pada berbagai konsentrasi berbeda-beda (Gambar 2).

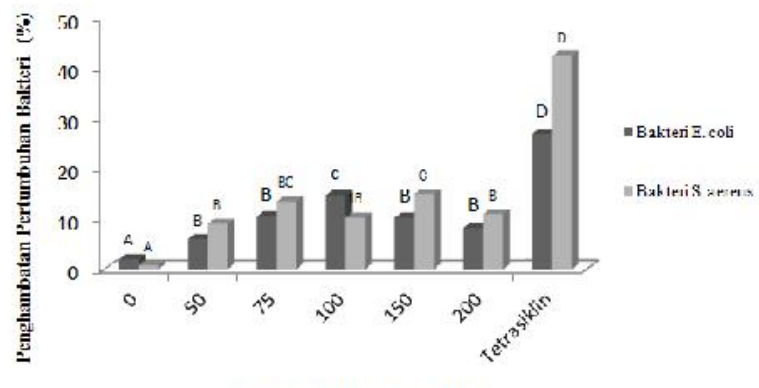

Konsentrasi Artemisin cina $\left(\mathrm{mg}^{\prime}\right)$

Gambar 2.Pola penghambatan ekstrak A. cina Berg ex Poljakov terhadap bakteri $E$. Coli dan $S$. aureus setelah masa inkubasi 24 jam 
Hasil analisis sidik ragam menunjukkan bahwa perlakuan konsentrasi ekstrak Artemisia cina yang diberikan pada bakteri $E$. coli dan $S$. aereus memberikan pengaruh nyata terhadap pertumbuhan kedua bakteri pada taraf 5\% (Tabel 1). Pemberian konsentrasi ekstrak Artemisia cina $100 \mathrm{mg} / \mathrm{l}$ menunjukkan penghambatan pertumbuhan bakteri $E$. coli yang nyata lebih tinggi dibandingkan pada perlakuan konsentrasi $0 \mathrm{mg} / \mathrm{l}, 50 \mathrm{mg} /$ 1, dan $75 \mathrm{mg} / 1$, selanjutnya peningkatan konsentrasi ekstrak Artemisia cina $150 \mathrm{mg} / \mathrm{l}$ dan $200 \mathrm{mg} / \mathrm{l}$ tidak mampu meningkatkan penghambatan terhadap pertumbuhan bakteri E.coli. Sedangkan respon S.aureus, perlakuan konsentrasi ekstrak Artemisia cina pada $150 \mathrm{mg} / \mathrm{l}$ menunjukkan penghambatan yang nyata lebih tinggi dibandingkan perlakuan 0mg/l, 50mg/l, 75mg/l, 100mg/l, selanjutnya peningkatan konsentrasi hingga $200 \mathrm{mg} / \mathrm{l}$ tidak mampu meningkatkan penghambatan pertumbuhan bakreri S.aereus. Dalam hal perlakuan bakteri terhadap konsentrasi ekstrak Artemisia cina hasil menunjukkan bahwa pemberian ekstrak Artemisia cina pada berbagai konsentrasi tidak menunjukkan perbedaan penghambatan pertumbuhan bakteri secara nyata pada E.coli dan S.aereus.

Tabel 1. Diameter daya hambat (DDH) oleh ekstrak $A$. cina Berg ex Poljakov terhadap bakteri E. coli dan $S$. aureus setelah masa inkubasi 24 jam

\begin{tabular}{ccc}
\hline $\begin{array}{c}\text { Konsentrasi ekstrak } \\
(\mathrm{mg} / \mathrm{l})\end{array}$ & \multicolumn{2}{c}{ Diameter daya hambat (rerata \pm SD $(\mathrm{mm}))$} \\
\cline { 2 - 3 } E. coli & S. aureus \\
\hline 0 & $2,00 \pm 1,68^{\mathrm{A}}$ & $0,75 \pm 0,96^{\mathrm{A}}$ \\
50 & $6,00 \pm 0,00^{\mathrm{B}}$ & $9,00 \pm 2,45^{\mathrm{B}}$ \\
75 & $10,50 \pm 6,66^{\mathrm{B}}$ & $13,50 \pm 2,38^{\mathrm{BC}}$ \\
100 & $14,75 \pm 5,91^{\mathrm{C}}$ & $10,25 \pm 2,63^{\mathrm{B}}$ \\
150 & $10,25 \pm 4,91^{\mathrm{B}}$ & $15,00 \pm 4,16^{\mathrm{C}}$ \\
200 & $8,25 \pm 3,11^{\mathrm{B}}$ & $11,00 \pm 1,15^{\mathrm{B}}$ \\
Tetrasiklin $^{2}$ & $27,00 \pm 11,49^{\mathrm{D}}$ & $42,50 \pm 9,57^{\mathrm{D}}$ \\
\hline
\end{tabular}

Ekstrak dimasukkan ke dalam sumuran mediaagar yang telah dispread dengan bakteri yang berdifusi pada media-agar supaya mempermudah penetrasi zat-zat, termasuk bahan aktif pada ekstrak dalam menghambat pertumbuhan bakteri (Pelczar dan Chan 1988). Aktivitas penghambatan terhadap pertumbuhan bakteri uji kemungkinan disebabkan oleh kandungan bahan aktif yang terdapat dalam ekstrak seperti senyawa flavonoid, alkaloid, minyak asiri, saponin, sterol dan triterpen, tanin, dan kumarin (Tabel 2 dan Gambar 3).
Tabel 2. Hasil penapisan fitokimia ekstrak Artemisia cina Berg. ex Poljakov

\begin{tabular}{clc}
\hline No. & \multicolumn{1}{c}{ Uji } & Hasil \\
\hline 1 & Flavonoid & + \\
2 & Alkaloid & + \\
3 & Minyak atsiri & ++ \\
4 & Saponin & + \\
5 & Sterol dan triterpena & + \\
6 & Tanin terhidrolisis & + \\
7 & Kumarin & ++ \\
\hline
\end{tabular}
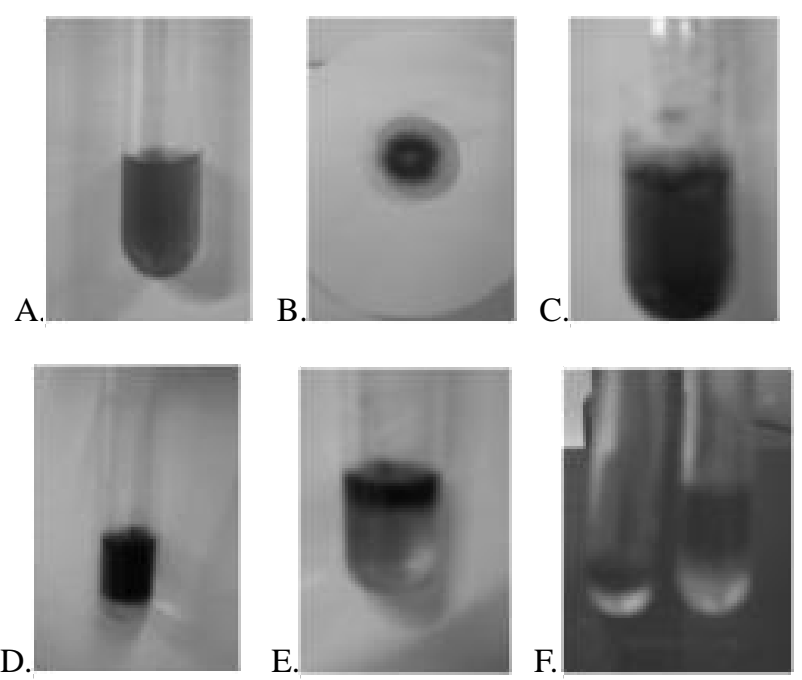

Gambar 3. Hasil pengujian fitokimia ekstrak ekstrak heksana petroleum eter $(1: 1 \mathrm{v} / \mathrm{v})$ Artemisia cina Berg. ex Poljakov. A. Uji flavonoid; B. Uji alkaloid; C. Uji saponin; D. Uji sterol dan triterpena; E. Uji tanin terhidrolisis; F. Uji kumarin

Cowan (1999) menyebutkan bahwa beberapa golongan senyawa bahan alam atau senyawa metabolit sekunder yang berpotensi sebagai antibakteri antara lain senyawa fenolik, polifenol, quinon, flavon, flavonoid, tanin, kumarin, terpenoid, alkanoid, lektin, dan polipeptida. Ekstrak heksana daun A. nilagirica mengandung alkaloid, asam amino, flavonoid, fenol, kuinina, tannin, dan terpenoid (Ahameethunisa dan Hopper, 2010), sementra dePadua et al. (1999) menyatakan bahwa kandungan senyawa-senyawa kimia yang terdapat dalam Artemisia cina antara lain flavonoid, asam fenol, kumarin, alkanoid, dan minyak asiri. Pada hasil pengujian penapisan fitokimia secara kualitatif dapat ditemukan adanya kandungan senyawa aktif lain yaitu sterol dan triterpen serta saponin.

Semakin besar kandungan bahan aktif dalam ekstrak, maka aktivitas penghambat akan 
bertambah. Akan tetapi sampai pada batas konsentrasi tertentu kemampuan daya hambat maksimal dan semakin menurun dengan bertambahnya konsentrasi. Hal tersebut diduga pada konsentrasi tinggi larutan semakin pekat sehingga daya difusi zat aktif semakin aktivitas daya hambat menurun.

Mekanisme kerja dari ekstrak Artemisia cina Berg. ex Poljakov kemungkinan bersifat bakteriostatik karena karena setelah rentang waktu pengamatan $24 \mathrm{jam}$, zona terang disekitar sumuran relatif tidak menunjukkan peingkatan aktivitas yang berarti. Jawetz et al. 1995 dan Setyaningsih 2004 menyatakan bahwa aktivitas bakteriostatik ditandai dengan terjadinya penghambatan perkembangbiakan bakteri, namun perkembangbiakan tersebut akan berlangsung kembali bila zat antibakteri telah berkurang atau habis.

Pada semua konsentrasi ekstrak yang diujikan, daya penghambat ekstrak terhadap pertumbuhan kedua jenis bakteri lebih kecil dibandingkan dengan daya hambat antibiotik standar tetrasiklin. Hal tersebut dikarenakan ekstrak masih merupakan ekstrak kasar (crude extract) yang merupakan campuran berbagai jenis senyawa yang tidak semuanya bersifat antibakteri sedangkan larutan standar antibiotik tetrasiklin hanya terkandung senyawa tunggal tertasiklin.

\section{KESIMPULAN}

Ekstrak Artemisia cina pada konsentrasi 100 $\mathrm{mg} / \mathrm{l}$ menunjukkan penghambatan pertumbuhan bakteri $E$. coli yang lebih tinggi dibandingkan pada perlakuan konsentrasi 0mg/l, 50mg/l, dan 75mg/l, perlakuan ekstrak Artemisia cina pada konsentrasi $150 \mathrm{mg} / \mathrm{l}$ menunjukkan penghambatan pertumbuhan $S$. Aureus yang nyata lebih tinggi dibandingkan perlakuan 0mg/l, 50mg/l, 75mg/l, 100mg/l. Ekstrak A. cina mengandung flavonoid, alkaloid, minyak esesial, saponin,sterol, triterpen, tanin dan coumarin.

\section{DAFTAR PUSTAKA}

Ahameethunisa, A.R. dan Hopper, W. 2010. Antibacterial activity of Artemisia nilagirica leaf extracts against clinical and phytopathogenic bacteria. BMC Complementary and Alternative Medicine 10 (6): 1-6.
Ahameethunisa, A.R. dan Hopper, W. 2012. In vitro antimicrobial activity on clinical microbial strains and antioxidant properties of Artemisia parviflora. Annals of Clinical Microbiology and Antimicrobials, 11 (30): 1-7.

Ahmadizadeh, C., Monadi, A., Rezaie, A., Pashazadeh, M., Jafari, B. 2014. Antibacterial Activity of Methanolic Extract and essence of Sagebrush (Artemisia vulgaris) against Pathogenic Bacteria. Bull. Env. Pharmacol. Life Sci., 3 (2): 121-125.

Budiyanto, A. W. 2006. Studi Awal Senyawa Antibakteri dari Ekstrak Buah Jambu Mete (Anacardium occidentale L.) Fraksi Kloroform. Skripsi. Program Studi Kimia, Fakultas Sains dan Matematika Universitas Kristen Satya Wacana. Salatiga.

Bibi, Y, Nisa, S, Chaudhary, F.M., Zia, M. 2011. Antibacterial activity of some selected medicinal plants of Pakistan. BMC Complementary and Alternative Medicine 11 (52): 1-7.

Cha, D-J. 2007. Chemical Composition and Antibacterial Activity Against Oral Bacteria by the Essential Oil of Artemisia iwayomogi. Journal of Bacteriology and Virology 37 (3) : 129 - 136.

Cowan, M. M. 1999. Plant Products as Antimicrobial Agents. Clinical Microbiology Reviews 12 (4): 564-582. (http:// cmr.asm.org/cgi/content/full/12/4/564).

DePadua, L. S., Bunyapraphatjara, N. dan Lemmens, R. H. M. J. 1999. Medicinal and Poisonous Plants I. Prosea Plant Resources of South East Asia 12: 139 147. Prosea Foundation. Bogor.

Dwiyanto, K. 2001. Peranan Plasma Nutfah Tumbuhan Obat dan Aromatik untuk Menunjang Kesinambungan Bahan Baku Industri. Simposium Nasional II Tumbuhan Obat dan Aromatik. Bogor. 5p.

Guangrong, H., J.Jiaxin, D. Dehui. 2008. Antioxidative and Antibacterial Activity of Methanol Extract of A. anomala S. Moore. African Journal of Biotechnology. 7 (9): 1335-1338. 
Habibipour, R., Rajabi, M. 2015. Antibacterial effects of Arctium lappa and Artemesia absinthium extracts in laboratory conditions. J HerbMed Pharmacol. 4(4): 133-137.

Imelouane, B., Bachiri, A.E.I., Ankit, M., Khedid, K., Wathelet, J.P., Amhamdi, H. Essential Oil Composition and Antimicrobial Activity of Artemisia Herba-alba Asso Grown in Maroco. Banat's Journal of Biotechnology. 1 (2): 48-55.

Jazani, N.H., Zarthoshti, M., babazadeh, H., Alidaiee, N. 2011. Antibacterial Effects of Artemisia dracunculus Essential Oil on Multi-drug Resistant Isolates of Acinobacter baumannii. Bacteriology Journal $1(1): 31-36$.

Jawetz, E., Melnick, J. L. and Adelberg, E. A. 1995. Mikrobiologi Kedokteran. Jakarta : Penerbit Buku Kedokteran EGC. 753pp.

Joshi, R.K. 2013. Artemisia capillaris: Medicinal uses and Future Source for Commercial Uses from Western Himalaya of Uttrakhand. Asian J. Res. Pharm. Sci. 3: (3): 137-140.

Kalemba, D., Kusewicz, D. dan Swiader, K. 2002. Antimicrobial Properties of the Essential Oil of Artemisia asiatica Nakai. PubMed 16 (13): 288 - 291.

Kasemi, M. Dakhili, M., Dadkhah, A., Yasrebifar, Z., Larijani, K. 2011. Composition, antimicrobial and antioxidant activities of the essential oil of Artemisia kermanensis Podl., anendemic species from Iran. Journal of Medicinal Plants Research $5(18)$ : 4481-4486.

Kim, K-H., Kim, B-C., Shin, C-G., Jeong, S.I. Kim, H.J., Ju, Y.S. 2004. Susceptibility of Oral Bacteria to Essential Oil of Artemisia capillaris Thunb. Korean Journal of Oriental Medicine. 25 ( 4) : 121-128.

Kim, Y-J., Lee, J-H., Kim, S-J. 2013. Cultivation characteristics and flavonoid contents of wormwood (Artemisia montana Pamp.). Journal of Agricultural Chemistry and Environment 2(4) : 117-122.
Kordali, S., Kotan, R., Mavi, A., Cakir, A., Ala, A. dan Yildirim, A. 2005. Determination of the Chemical Composition and Antioxidant Activity of the Essential oil of Artemisia dracunculus of Turkish Artemisia absinthium, Artemisia dracunculus, Artemisia santonicum and Artemisia spicigera Essential Oils. Agric. Food. Chem. 53 (24) : 9452 - 9458.

More, G., Lall, N., Hussein, A., Tshikalange, T.E. 2012. Antimicrobial Constituents of Artemisia afra Jacq. ex Willd. against Periodontal Pathogens. Evidence-Based Complementary and Alternative Medicine. 1-7.

Moslemi, H.R., Hoseinzadeh, H., Badouei, M.A., Kafshdouzan, K., Fard, R.M.N. 2010. Antimicrobial Activity of Artemisia absinthium Against Surgical Wounds Infected by Staphylococcus aureus in a Rat Model. Indian J Microbiol 52 (4) : 601604.

Muleya, E., Ahmed, A.S., Sipamla, A.M., Mtunzi, F.M., Mutatu W. 2014. Evaluation of Anti-Microbial, Anti-Inflammatory and Anti-Oxidative Properties Artemisia afra, Gunnera perpensa and Eucomis autumnalis. J Nutr Food Sci. 4 (6) : 1-6.

Pelczar, M. J. dan Chan, E. C. S. 1988. DasarDasar Mikrobiologi 2. Jakarta: Universitas Indonesia Press. 576pp.

Raeisi, M., Tajik, H., Razavi roohani, S.M., Maham, M., Moradi, M., Hajimohammadi, B., Naghili, H., Hashemi, M., Mehdizadeh, T. 2012. Essential oil of tarragon (Artemisia dracunculus) antibacterial activity on Staphylococcus aureus and Escherichia coli in culture media and Iranian white cheese. Iranian Journal of Microbiology. 4 (1) : 30-34.

Setzer, W. N., Vogler, B., Schmidt, J. M., Leahy, J. G. dan Rives, R. 2004. Antimicrobial Activity of Artemisia douglasiana Leaf Essential Oil. Fitoterapia 75 (2): 192-200.

Setyaningsih, I. 2003. Resistensi Bakteri dan Antibiotik Alami dari Laut. Makalah Falsafah Sains, Sekolah Pasca Sarjana Institut Pertanian Bogor. Bogor. 
Sharma, V. Singh, B., Gupta, R.C., Dhaliwal, H.S., Srivastava, D.K. 2014. In vitro antimicrobial activity and GCMS analysis of essential oil of Artemisia maritima (Linn.) from Lahaul \& Spiti (Cold Desert) egion of North-Indian higher altitude Himalayas. Journal of Medicinal Plants Studies. 2 (1): 45-52.

Stermitz, F. R., Scriven, L. N., Tegos, G. dan Lewis, K. 2002. Two Flavonols from Artemisia cina whch Potentiate the Activity of Berberine and Norfloxacin Against a Resistant Strain of Staphylococcus aureus. Planta Med. 68 (12): $1140-1141$.

Tajehmiri1, A., Issapour, F., Moslem, M.N., Lakeh, M.T., Kolavani, M.H. 2014. In vitro Antimicrobial Activity of Artemisia annua Leaf Extracts against Pathogenic Bacteria. Advanced Studies in Biology. 6 (3): 93 - 97.
Tan, R. X., Zheng, W. F. dan Tang, H. Q. 1998. Biological Active Substanc from Genus Artemisia. Nanjing University, Nanjing, P. R. China

Zhang, J., Shi, B., Gao, P., Wang, J., Wu, W. 2012. Composition, in vitro antioxidant and antimicrobial activity of the essential oils from Artemisia lavandulaefolia $D C$. Journal of Medicinal Plants Research 6(7): 1284-1288.

Zouari, S. Zouari, N., Fakhfakh, N., Bougatef, A., Ayadi, M.A., Neffati, M. 2010. Chemical composition and biological activities of a new essential oil chemotype of Tunisian Artemisia herba alba Asso. Journal of Medicinal Plants Research 4 (10): 871880. 